\title{
Penerapan Metode AHP Dan TOPSIS Untuk Mengevaluasi Pemohon Kredit Suku Cadang Motor Suzuki (Studi Kasus : PT. Riau Jaya Cemerlang Pekanbaru)
}

\author{
Mursalim $^{1}$, Mardainis ${ }^{2}$ \\ (Program Studi Teknik Informatika STMIK Amik Riau) \\ (Jl. Purwodadi Indah Km. 10 Panam - Pekanbaru, Telp. 0761-589561) \\ (e-mail: ${ }^{1}$ alim_03588@yahoo.com, ${ }^{2}$ mardainis@ @stmik-amik-riau.ac.id)
}

\begin{abstract}
Abstrak
Dalam pemberian kredit kepada pelanggan banyak hal perlu dipertimbangkan agar keputusan yang diambil tidak salah. Biasanya dilakukan pengumpulan beberapa persyaratan administrasi serta melakukan penilaian terhadap jaminan seperti aset yang dimiliki, nilai ekonomi dan beberapa pertimbangan lainnya, sehingga proses pengambilan keputusan butuh waktu lama. Dalam penelitian ini dibangun suatu sistem pendukung keputusan untuk menentukan pemberian kredit kepada konsumen dengan menerapkan dua metode yaitu Analytical Hierarchy Process (AHP).
\end{abstract}

Kata kunci: $A H P$, Kredit, Suku Cadang.

\section{Abstract}

In granting credit to customers a lot of things need to be considered so that the decisions are not wrong. Usually done some administrative requirements gathering and assessment of collateral as assets, economic value and some other considerations, so that the decision-making process takes a long time. In this study constructed a decision support system for determining lending to consumers by applying two methods: Analytical Hierarchy Process (AHP.

Keywords: AHP, Credit, Parts.

\section{Pendahuluan}

\subsection{Latar Belakang Masalah}

PT. Riau Jaya Cemerlang Pekanbaru merupakan perusahaan yang bergerak di bidang penjualan sepeda motor dan suku cadang sepeda motor. Penjualan suku cadang sepeda motor dilakukan juga oleh pihak kedua yang mengambil barang ke PT. Riau Jaya Cemerlang dengan sistim pembayaran secara tunai maupun kredit. Oleh sebab itu perusahaan harus selektif untuk memberikan kredit kepada pihak kedua agar jangan sampai terjadi masalah dikemudian hari, seperti kredit macet. Saat ini penentuan pemberian kredit kepada pemohon masih dilakukan secara manual yakni dengan mengumpulkan persyaratan administrasi dan proses wawancara. Selain persyaratan administrasi masih ada beberapa hal yang harus dievaluasi oleh pihak pengambil keputusan di PT. Riau Jaya Cemerlang Cabang Pekanbaru terkait pemberian kredit suku cadang, diantaranya harus mempertimbangkan aset yang dimiliki pemohon, nilai ekonomi pemohon dan beberapa pertimbangan lainnya. Salah satu cara yang bisa digunakan untuk penyelesaian masalah tersebut adalah dengan menggunakan metode AHP.

Menurut Marimin dan Maghfiroh (2010), AHP memiliki banyak keunggulan dalam menjelaskan proses pengambilan keputusan karena dapat digambarkan secara grafis, sehingga mudah dipahami oleh semua pihak yang terlibat dalam pengambilan keputusan tersebut. Dengan 
AHP, proses keputusan kompleks dapat diuraikan menjadi keputusan- keputusan lebih kecil yang dapat ditangani dengan mudah.[1]

Beberapa masalah yang teridentifikasi adalah :

1. Penentuan pemberian kredit kepada pemohon masih dilakukan secara manual yakni dengan mengumpulkan persyaratan administrasi dan proses wawancara.

2. Banyaknya persyaratan yang harus dievaluasi oleh pihak pengambil keputusan dalam memutuskan pemohon yang layak mendapatkan kredit suku cadang.

3. Penilaian hanya dicatat pada kertas kemudian mengarsipkan dokumen sehingga pengambilan keputusan membutuhkan waktu yang lama.

4. Pembuatan laporan memakan waktu karena harus melakukan perekapan data terlebih dahulu.

\subsection{Rumusan Masalah}

Berdasarkan latar belakang di atas maka penelitian ini merumuskan masalah adalah :

1. Bagaimana memutuskan persetujuan kredit konsumen pada PT. Riau Jaya Cemerlang Pekanbaru)?

2. Bagaimana aplikasi yang dibangun dapat menetapkan keputusan customer yang layak diberikan kredit?

\subsection{Batasan Masalah}

Agar penelitian ini terarah maka peneliti menetapkan batasan masalah yaitu sebagai berikut

1. Penelitian ini bertujuan untuk menghasilkan aplikasi yang dapat memberikan keputusan pemohon kredit yang layak dan yang tidak layak.

2. Sistem menyajikan hasil penerapan metode Analytical Hierarchy Process (AHP) dalam mengevaluasi pemohon kredit.

Berdasarkan uraian di atas, maka perlu dirancang suatu sistem pendukung keputusan berbasis komputer dengan metode Analitycal Hierarchy Process (AHP). [2]

\subsection{Tujuan dan Manfaat Penelitian}

Adapun yang menjadi tujuan dan manfaat dari penelitian adalah untuk dapat mengembangkan suatu aplikasi berbasis web yang dapat mengevaluasi pemohon kredit suku cadang motor Suzuki pada PT. Riau Jaya Cemerlang Pekanbaru dengan mengimplementasikan metode AHP.

\section{Metode Penelitian}

Analitycal Hierarchy Process (AHP) Adalah metode untuk memecahkan suatu situasi yang komplek tidak terstruktur kedalam beberapa komponen dalam susunan yang hirarki, dengan memberi nilai subjektif tentang pentingnya setiap variabel secara relatif, dan menetapkan variabel mana yang memiliki prioritas paling tinggi guna mempengaruhi hasil pada situasi tersebut.[3]

Proses hierarki analitik (Analitycal Hierarchy Process) dikembangkan oleh Dr. Thomas L. Saaty dari Wharton School of Business pada tahun 1970-an untuk mengorganisir informasi dari pendapat ahli (judgment) dalam memilih alternatif yang paling disukai (Marimin, 2011:91).

Pada dasarnya, prosedur atau langkah-langkah dalam metode AHP meliputi (Kusrini, 2007:135-137):

1. Mendefenisikan masalah dan menentukan solusi yang diinginkan, lalu menyusun hierarki dari permasalahan yang dihadapi.

2. Menentukan prioritas elemen 


\subsection{Analisa Perhitungan Manual Metode AHP}

Pada analisa perhitungan AHP ini akan dijelaskan implementasi manual metode AHP. Sebelum diberikan contoh kasus dan langkah-langkah penyelesaiannya, perlu ditentukan terlebih dahulu kriteria dan subkriteria yang digunakan dalam penilaian. Kriteria yang digunakan dalam mengevaluasi pemohon kredit terdiri dari beberapa aspek. Kriteria penilaian disajikan dalam Tabel 1.

\section{Tabel 1. Kriteria Penilaian}

\begin{tabular}{|c|c|}
\hline Kode & Kriteria \\
\hline K1 & Jumlah pembelian oli selama tiga bulan berturut-turut \\
\hline K2 & Rekening koran milik pemohon \\
\hline K3 & Laba bersih perusahaan \\
\hline K4 & Aset yang dimiliki perusahaan \\
\hline K5 & Kelengkapan administrasi \\
\hline
\end{tabular}

Kriteria penilaian tersebut di atas masing-masing memiliki subkriteria. Adapun subkriteria dari kriteria penilaian di atas dapat dilihat pada Tabel 2.

Tabel 2. Subkriteria Penilaian

\begin{tabular}{|c|c|c|}
\hline Kode Kriteria & Subkriteria & Rating Kecocokan \\
\hline \multirow{2}{*}{ K1 } & $>1000$ unit & 3 \\
& $500-1000$ unit & 2 \\
& $<500$ unit & 1 \\
\hline \multirow{2}{*}{ K2 } & $\geq 50$ juta & 2 \\
& $<50$ juta & 1 \\
\hline \multirow{2}{*}{ K3 } & Tinggi (>500 Juta) & 3 \\
& Cukup (100 Juta -500 Juta) & 2 \\
& Rendah (<100 Juta) & 1 \\
\hline \multirow{2}{*}{ K4 } & Tinggi (>10 Milyar) & 3 \\
& Cukup ( 1 Milyar - 10 Milyar) & 2 \\
\multirow{2}{*}{ K5 } & Rendah (<1 Milyar) & 1 \\
\hline & Lengkap & 2 \\
& Tidak Lengkap & 1 \\
\hline
\end{tabular}

\subsubsection{Analisa Perhitungan Metode Analytical Hierarchy Process (AHP)} berikut :

Adapun langkah-langkah perhitungan dengan metode AHP ini dijabarkan sebagai

\section{Menentukan Prioritas Kriteria}

1. Membuat matriks perbandingan berpasangan

Pada tahap ini dilakukan penilaian perbandingan antara satu kriteria dengan kriteria yang lain. Hasil matriks perbandingan berpasangan kriteria ditunjukkan oleh Tabel 3. 
Tabel 3. Matriks Perbandingan Berpasangan Kriteria

\begin{tabular}{|c|c|c|c|c|c|}
\hline Kriteria & $\mathrm{K} 1$ & $\mathrm{~K} 2$ & $\mathrm{~K} 3$ & $\mathrm{~K} 4$ & $\mathrm{~K} 5$ \\
\hline $\mathrm{K} 1$ & 1 & 2 & 3 & 5 & 6 \\
\hline $\mathrm{K} 2$ & $1 / 2$ & 1 & 2 & 3 & 4 \\
\hline $\mathrm{K} 3$ & $1 / 3$ & $1 / 2$ & 1 & 2 & 3 \\
\hline $\mathrm{K} 4$ & $1 / 5$ & $1 / 3$ & $1 / 2$ & 1 & 2 \\
\hline $\mathrm{K} 5$ & $1 / 6$ & $1 / 4$ & $1 / 3$ & $1 / 2$ & 1 \\
\hline Total & 2.20 & 4.08 & 6.83 & 11.50 & 16 \\
\hline
\end{tabular}

Angka 1 pada Baris K1 kolom K1 menggambarkan tingkat kepentingan yang sama antara $\mathrm{K} 1$ dengan $\mathrm{K} 1$, sedangkan angka 2 pada baris $\mathrm{K} 1$ kolom $\mathrm{K} 2$ menunjukkan nilai tengah antara dua nilai keputusan yang berdekatan. Angka 0.5 pada baris K2 kolom K1 merupakan hasil perhitungan 1/nilai pada kolom K2 baris K1 (2). Angka-angka yang lain diperoleh dengan cara yang sama.

2. Membuat matriks nilai kriteria

Tabel 4. adalah hasil dari matriks nilai kriteria, diperoleh dengan rumus nilai baris kolom baru $=$ nilai baris - kolom/jumlah masing kolom lama.

Tabel 4. Matriks Nilai Kriteria

\begin{tabular}{|c|c|c|c|c|c|c|c|}
\hline $\begin{array}{l}\text { Krit } \\
\text { eria }\end{array}$ & K1 & K2 & K3 & K4 & K5 & Jumlah & $\begin{array}{l}\text { Priori } \\
\text { tas }\end{array}$ \\
\hline K1 & $\begin{array}{c}1 / 2.20= \\
0.45\end{array}$ & $\begin{array}{c}2 / 4.08= \\
0.49\end{array}$ & $\begin{array}{c}3 / 6.83= \\
0.44\end{array}$ & $\begin{array}{c}5 / 11.50= \\
0.43\end{array}$ & $\begin{array}{c}6 / 16 \\
=0.38\end{array}$ & $\begin{array}{c}0.45+0.49+0.44+0 \\
.43+0.38=2.19\end{array}$ & $\begin{array}{l}2.19 / 5 \\
=0.44\end{array}$ \\
\hline K2 & $\begin{array}{c}0.50 / 2.2 \\
0=0.23\end{array}$ & $\begin{array}{c}1 / 4.08= \\
0.24\end{array}$ & $\begin{array}{c}2 / 6.83= \\
0.29\end{array}$ & $\begin{array}{c}3 / 11.50= \\
0.26\end{array}$ & $\begin{array}{r}4 / 16 \\
=0.25 \\
\end{array}$ & $\begin{array}{c}0.23+0.24=0.29+0 \\
.26+0.25=1.28\end{array}$ & $\begin{array}{l}1.28 / 5 \\
=0.26 \\
\end{array}$ \\
\hline K3 & $\begin{array}{c}0.33 / 2.2 \\
0=0.15\end{array}$ & $\begin{array}{c}0.5 / 4.08 \\
=0.12\end{array}$ & $\begin{array}{c}1 / 6.83= \\
0.15\end{array}$ & $\begin{array}{c}2 / 11.50= \\
0.17\end{array}$ & $\begin{array}{c}3 / 16 \\
=0.19\end{array}$ & $\begin{array}{c}0.15+0.12+0.15+0 \\
.17+0.19=0.78\end{array}$ & $\begin{array}{l}0.78 / 5 \\
=0.16\end{array}$ \\
\hline K4 & $\begin{array}{c}0.20 / 2.2 \\
0=0.09\end{array}$ & $\begin{array}{c}0.33 / 4.0 \\
8=0.08\end{array}$ & $\begin{array}{l}0.50 / 6.8 \\
3=0.07\end{array}$ & $\begin{array}{c}1 / 11.50= \\
0.09\end{array}$ & $\begin{aligned} & 2 / 16 \\
= & 0.13\end{aligned}$ & $\begin{array}{c}0.09+0.08+0.07+0 \\
.09+0.13=0.46\end{array}$ & $\begin{array}{l}0.46 / 5 \\
=0.09\end{array}$ \\
\hline K5 & $\begin{array}{c}0.17 / 2.2 \\
0=0.08\end{array}$ & $\begin{array}{c}0.25 / 4.0 \\
8=0.06\end{array}$ & $\begin{array}{l}0.33 / 6.8 \\
3=0.05\end{array}$ & $\begin{array}{l}0.50 / 11 \\
50=0.04\end{array}$ & $\begin{aligned} & 1 / 16 \\
= & 0.06\end{aligned}$ & $\begin{array}{c}0.08+0.06+0.05+0 \\
.04+0.06=0.29\end{array}$ & $\begin{array}{l}0.29 / 5 \\
=0.06\end{array}$ \\
\hline
\end{tabular}

Nilai 0.45 pada baris K1 kolom K1 diperoleh dari nilai baris K1 kolom K1 pada Tabel 1.3 dibagi jumlah kolom K1 Tabel 3. Nilai pada kolom prioritas diperoleh dari nilai pada kolom jumlah dibagi dengan jumlah kriteria, dalam hal ini 5. Kolom prioritas kriteria baris $\mathrm{K} 2(0,26)$ didapat dari 1,28 dibagi 5 , begitu seterusnya.

3. Membuat matriks penjumlahan setiap baris

Matrik penjumlahan setiap baris dibuat dengan mengalikan nilai prioritas pada Tabel 4. dengan matriks perbandingan berpasangan pada Tabel 2. Hasil dari matriks penjumlahan setiap baris ditunjukkan oleh Tabel 5 .

Tabel 5. Matriks Penjumlahan Setiap Baris Kriteria

\begin{tabular}{|c|c|c|c|c|c|c|}
\hline $\begin{array}{c}\text { Krite } \\
\text { ria }\end{array}$ & K1 & K2 & K3 & K4 & K5 & Jumlah \\
\hline K1 & $1 \times 0.44=0$. & $2 \times 0.44=0$. & $3 \times 0.44=1$. & $5 \times 0.44=2$. & $6 \times 0.44=$ & $0.44+0.88+1.32+2.19+$ \\
& 44 & 88 & 32 & 19 & 2.63 & $2.63=7.46$ \\
\hline K2 & $0.50 \times 0.26$ & $1 \times 0.26=0$. & $2 \times 0.26=0$. & $3 \times 0.26=0$. & $4 \times 0.26=$ & $0.13+0.26+0.51+0.77+$ \\
& $=0.13$ & 26 & 51 & 77 & 1.02 & $1.02=2.68$ \\
\hline K3 & $0.33 \times 0.16$ & $0.5 \times 0.16=$ & $1 \times 0.16=0$. & $2 \times 0.16=0$. & $3 \times 0.16=$ & $0.05+0.08+0.16+0.31+$ \\
& $=0.05$ & 0.08 & 16 & 31 & 0.47 & $0.47=1.07$ \\
\hline
\end{tabular}




\begin{tabular}{|c|c|c|c|c|c|c|}
\hline K4 & $0.20 \times 0.09$ & $0.33 \times 0.09$ & $0.50 \times 0.09$ & $1 \times 0.09=0$. & $2 \times 0.09=$ & $0.02+0.03+0.05+0.09+$ \\
& $=0.02$ & $=0.03$ & $=0.05$ & 09 & 0.18 & $0.18=0.37$ \\
\hline K5 & $0.17 \times 0.06$ & $025 \times 0.06=$ & $0.33 \times 0.06$ & $0.50 \times 0.06$ & $1 \times 0.06=$ & $0.01+0.01+0.02+0.03+$ \\
& $=0.01$ & 0.02 & $=0.02$ & $=0.03$ & 0.06 & $0.06=0.13$ \\
\hline
\end{tabular}

Nilai 0.44 pada baris K1 kolom K1 diperoleh dari prioritas baris K1 pada Tabel $1.4(0.44)$ dikalikan dengan nilai baris K1 kolom K1 pada Tabel 1.3 (1). Kolom jumlah diperoleh dengan menjumlahkan nilai pada masing-masing baris pada tabel tersebut. Misalnya, nilai 7.46 pada kolom jumlah merupakan hasil penjumlahan dari $0.44+0.88+1.32+2.19+2.63=7.46$.

4. Penghitungan rasio konsistensi

Perhitungan ini digunakan untuk memastikan bahwa nilai rasio konsistensi $(\mathrm{CR})<=0,1$. Jika ternyata nilai CR lebih besar dari 0,1 maka matriks perbandingan berpasangan harus diperbaiki. Hasil perhitungan rasio konsistensi ditunjukkan oleh Tabel 6.

Tabel 6. Penghitungan Rasio Konsistensi

\begin{tabular}{|c|c|c|c|}
\hline Kriteria & Jumlah Per Baris & Prioritas & Hasil \\
\hline K1 & 7.46 & 0.44 & $7.46+0.44=7.90$ \\
\hline K2 & 2.68 & 0.26 & $2.68+0.26=2.93$ \\
\hline K3 & 1.07 & 0.16 & $1.07+0.16=1.22$ \\
\hline K4 & 0.37 & 0.09 & $0.37+0.09=0.46$ \\
\hline K5 & 0.13 & 0.06 & $0.13+0.06=0.19$ \\
\hline \multicolumn{3}{|c|}{ Jumlah } & 12.70 \\
\hline
\end{tabular}

Dari tabel di atas diperoleh nilai-nilai sebagai berikut :

$\begin{array}{ll}\text { Jumlah seluruh hasil } & =12.70 \\ \mathrm{n}(\text { jumlah kriteria }) & =5 \\ \lambda \text { maks }(\text { jumlah } / \mathrm{n}) & =12.70 / 5=2.54 \\ \mathrm{CI}((\lambda \text { maks }-\mathrm{n}) / \mathrm{n}) & =(2.54-5) / 5=-0.49 \\ \mathrm{IR} \text { matriks } 5 \times 5 & =1.12 \\ \mathrm{CR}(\mathrm{CI}: \mathrm{IR}) & =-0.44\end{array}$

Oleh karena itu $\mathrm{CR}<0,1$ karena $-0,44<0,1$, maka rasio konsistensi dari perhitungan tersebut bisa diterima.

\section{Menentukan Prioritas Subkriteria}

Berikut ini diberikan contoh perhitungan prioritas subkriteria K1 yaitu kriteria jumlah pembelian oli selama tiga bulan berturut-turut. Langkah-langkah yang dilakukan adalah sebagai berikut :

1. Membuat matriks perbandingan berpasangan

Hasil dari perhitungan matriks perbandingan berpasangan subkriteria jumlah pembelian oli selama tiga bulan berturut-turut dapat dilihat pada Tabel 7.

Tabel 7. Matriks Perbandingan Berpasangan Subkriteria K1

\begin{tabular}{|c|c|c|c|}
\hline Subkriteria & $>1000$ unit & $500-1000$ unit & $<500$ unit \\
\hline$>1000$ unit & 1 & 3 & 5 \\
\hline
\end{tabular}




\begin{tabular}{|c|c|c|c|}
$500-1000$ unit & 0.33 & 1 & 2 \\
\hline$<500$ unit & 0.2 & 0.50 & 1 \\
\hline Total & 1.53 & 4.50 & 8.00 \\
\hline
\end{tabular}

Angka 1 pada kolom > 1000 unit Baris > 1000 unit menggambarkan tingkat kepentingan yang sama antara keduanya, sedangkan angka 3 pada kolom $500-1000$ unit baris $>1000$ unit menunjukkan > 1000 unit sedikit lebih penting dari $500-1000$ unit. Angka 0.33 merupakan hasil perhitungan 1/nilai pada kolom $500-1000$ unit baris > 1000 unit (3). Angka-angka yang lain diperoleh dengan cara yang sama.

2. Membuat matriks nilai subkriteria

Langkah ini seperti yang dilakukan pada langkah sebelumnya. Perbedaannya adalah adanya tambahan kolom prioritas subkriteria pada langkah ini. Hasilnya dapat dilihat pada Tabel 8.

Tabel 8. Matriks Nilai Subkriteria K1

\begin{tabular}{|c|c|c|c|c|c|c|}
\hline Subkriteria & $\begin{array}{c}>1000 \\
\text { unit }\end{array}$ & $\begin{array}{c}500-1000 \\
\text { unit }\end{array}$ & $\begin{array}{c}<500 \\
\text { unit }\end{array}$ & Jlh & $\begin{array}{c}\text { Priorit } \\
\text { as }\end{array}$ & $\begin{array}{c}\text { Prioritas } \\
\text { Subkriteria }\end{array}$ \\
\hline$>1000$ unit & 0.65 & 0.67 & 0.63 & $\begin{array}{c}1.9 \\
4\end{array}$ & 0.65 & 1 \\
\hline $\begin{array}{c}500-1000 \\
\text { unit }\end{array}$ & 0.22 & 0.22 & 0.25 & $\begin{array}{c}0.6 \\
9\end{array}$ & 0.23 & 0.35 \\
\hline$<500$ unit & 0.13 & 0.11 & 0.13 & $\begin{array}{c}0.3 \\
7\end{array}$ & 0.12 & 0.19 \\
\hline
\end{tabular}

Nilai 0.65 pada kolom > 1000 unit baris $>1000$ unit diperoleh dari nilai kolom > 1000 unit baris > 1000 unit pada Tabel 1.7 dibagi jumlah kolom > 1000 unit Tabel 7. Nilai kolom jumlah pada Tabel 1.7 diperoleh dari penjumlahan pada setiap barisnya. Untuk baris pertama nilai 1.94 merupakan hasil penjumlahan dari $0.65+0.67+0.63=1.94$. Nilai pada kolom prioritas diperoleh dari nilai pada kolom jumlah dibagi dengan jumlah subkriteria, dalam hal ini 3. Sedangkan prioritas subkriteria didapat dari membagi nilai pada kolom prioritas dengan nilai terbesar dari seluruh nilai pada kolom prioritas yang dalam hal ini adalah 0.65 .

3. Membuat matriks penjumlahan setiap baris

Matrik penjumlahan setiap baris dibuat dengan mengalikan nilai prioritas dengan matriks perbandingan berpasangan. Matriks penjumlahan setiap baris ditunjukkan oleh Tabel 9 .

Tabel 9. Matriks Penjumlahan Setiap Baris Subkriteria K1

\begin{tabular}{|c|c|c|c|c|}
\hline & $>1000$ unit & $500-1000$ unit & $<500$ unit & Jumlah \\
\hline$>1000$ unit & 0.65 & 1.94 & 3.24 & 5.83 \\
\hline $500-1000$ unit & 0.08 & 0.23 & 0.46 & 0.77 \\
\hline$<500$ unit & 0.02 & 0.06 & 0.12 & 0.21 \\
\hline
\end{tabular}

Nilai 0.65 pada baris $>1000$ unit kolom $>1000$ unit diperoleh dari prioritas baris $>1000$ unit pada Tabel 1.8 (0.65) dikalikan dengan nilai baris > 1000 unit kolom > 1000 unit pada Tabel 1.7 (1). Kolom jumlah diperoleh dengan menjumlahkan nilai pada masingmasing baris pada Tabel 9. Misalnya, nilai 5.83 pada kolom jumlah merupakan hasil penjumlahan dari $0.65+1.94+3.24=5.83$. 
4. Penghitungan rasio konsistensi

Perhitungan ini digunakan untuk memastikan bahwa nilai rasio konsistensi $(\mathrm{CR})<=0,1$. Jika ternyata nilai CR lebih besar dari 0,1 maka matriks perbandingan berpasangan harus diperbaiki. Perhitungan rasio konsistensi ditunjukkan oleh Tabel 10.

Tabel 10. Penghitungan Rasio Konsistensi

\begin{tabular}{|c|c|c|c|}
\hline & Jumlah Per Baris & Prioritas & Hasil \\
\hline$>1000$ unit & 5.83 & 0.65 & 6.48 \\
\hline $500-1000$ unit & 0.77 & 0.23 & 1.00 \\
\hline$<500$ unit & 0.21 & 0.12 & 0.33 \\
\hline
\end{tabular}

Dari tabel di atas diperoleh nilai-nilai sebagai berikut :

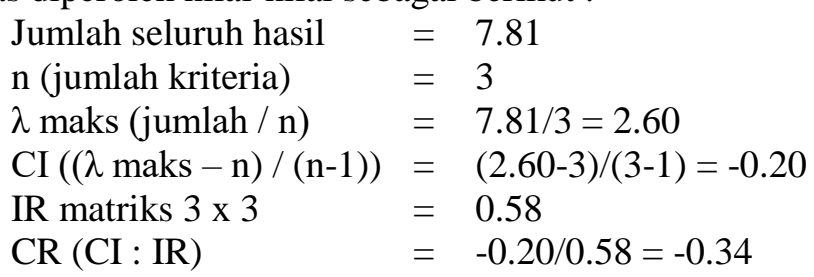

Oleh karena itu $\mathrm{CR}<0,1$ karena $-0,34<0,1$, maka rasio konsistensi dari perhitungan tersebut bisa diterima.

\section{Menghitung Hasil Akhir}

Langkah perhitungan prioritas subkriteria untuk kriteria yang lainnya dilakukan dengan cara yang sama. Dari perhitungan prioritas kriteria dan prioritas subkriteria di atas, maka dapat disusun tabel prioritas kriteria dan prioritas subkriteria seperti yang ditunjukkan oleh Tabel 11.

Tabel 11. Prioritas Kriteria dan Subkriteria

\begin{tabular}{|c|c|c|c|}
\hline Kriteria & Prioritas Kriteria & Subkriteria & Prioritas Subkriteria \\
\hline K1 & 0.44 & $\begin{array}{l}>1000 \text { unit } \\
500-1000 \text { unit } \\
<500 \text { unit }\end{array}$ & $\begin{array}{l}1 \\
0.35 \\
0.19\end{array}$ \\
\hline K2 & 0.26 & $\begin{array}{l}\geq 50 \text { juta } \\
<50 \text { juta }\end{array}$ & $\begin{array}{l}1 \\
0.50\end{array}$ \\
\hline K3 & 0.16 & $\begin{array}{l}\text { Tinggi } \\
\text { Cukup } \\
\text { Rendah }\end{array}$ & $\begin{array}{l}1 \\
0.55 \\
0.30\end{array}$ \\
\hline K4 & 0.09 & $\begin{array}{l}\text { Tinggi } \\
\text { Cukup } \\
\text { Rendah }\end{array}$ & $\begin{array}{l}1 \\
0.46 \\
0.22\end{array}$ \\
\hline K5 & 0.06 & $\begin{array}{l}\text { Lengkap } \\
\text { Tidak Lengkap }\end{array}$ & $\begin{array}{l}1 \\
0.5\end{array}$ \\
\hline
\end{tabular}

Berikut ini diberikan contoh data penilaian kriteria tiga pemohon seperti yang terlihat pada Tabel 12. 
Tabel 12. Data Penilaian Pemohon

\begin{tabular}{|c|c|c|c|c|c|}
\hline Nama pemohon & K1 & K2 & K3 & K4 & K5 \\
\hline Pemohon A & $500-1000$ unit & $<50$ juta & Tinggi & Tinggi & Lengkap \\
\hline Pemohon B & $500-1000$ unit & $\geq 50$ juta & Tinggi & Cukup & Lengkap \\
\hline Pemohon C & $<500$ unit & $\geq 50$ juta & Cukup & Rendah & Lengkap \\
\hline
\end{tabular}

Dari data tersebut, maka hasil penilaian yang diperoleh masing-masing pemohon adalah :

Pemohon $\mathrm{A}_{\mathrm{K} 1}=0.44 \times 0.35=0.15$

Pemohon $\mathrm{A}_{\mathrm{K} 2}=0.26 \times 0,50=0.13$

Pemohon $\mathrm{A}_{\mathrm{K} 3}=0.16 \times 1=0.16$

Pemohon $\mathrm{A}_{\mathrm{K} 4}=0.09 \times 1=0.09$

Pemohon $\mathrm{A}_{\mathrm{K} 5}=0.06 \times 1=0.06$

Pemohon $\mathrm{B}_{\mathrm{K} 1}=0.44 \times 0.35=0.15$

Pemohon $\mathrm{B}_{\mathrm{K} 2}=0.26 \times 1=0.26$

Pemohon $\mathrm{B}_{\mathrm{K} 3}=0.16 \times 1=0.16$

Pemohon $\mathrm{B}_{\mathrm{K} 4}=0.09 \times 0.46=0.04$

Pemohon $\mathrm{B}_{\mathrm{K} 5}=0.06 \times 1=0.06$

Pemohon $\mathrm{C}_{\mathrm{K} 1}=0.44 \times 0.19=0.08$

Pemohon $\mathrm{C}_{\mathrm{K} 2}=0.26 \times 1=0.26$

Pemohon $\mathrm{C}_{\mathrm{K} 3}=0.16 \times 0.55=0.08$

Pemohon $\mathrm{C}_{\mathrm{K} 4}=0.09 \times 0.22=0.02$

Pemohon $\mathrm{C}_{\mathrm{K} 5}=0.06 \times 1=0.06$

Selanjutnya hasil akhir penilaian dengan metode AHP di atas disusun seperti yang ditunjukkan oleh Tabel 13.

Tabel 13. Hasil Akhir Penilaian Dengan Metode AHP

\begin{tabular}{|c|c|c|c|c|c|c|}
\hline Nama pemohon & K1 & K2 & K3 & K4 & K5 & Total \\
\hline Pemohon A & 0.15 & 0.13 & 0.16 & 0.09 & 0.06 & 0,59 \\
\hline Pemohon B & 0.15 & 0.26 & 0.16 & 0.04 & 0.06 & 0,67 \\
\hline Pemohon C & 0.08 & 0.26 & 0.08 & 0.02 & 0.06 & 0,50 \\
\hline
\end{tabular}

Berdasarkan Tabel 1.13 yaitu hasil akhir penilaian dengan metode AHP dapat dilihat bahwa pemohon $\mathrm{B}$ memperoleh total nilai tertinggi sehingga berada di peringkat pertama, Pemohon A di peringkat kedua dan pemohon $C$ di peringkat ketiga. Dengan kata lain pemohon B dapat dijadikan pertimbangan pertama untuk mendapatkan kredit suku cadang dari perusahaan.

\subsection{Perancangan Sistem}

Setelah memecahkan masalah pada tahap analisa maka tahap selanjutnya adalah membuat perancangan atau desain sistem yang baru. Salah satu alat pengembangan sistem yang digunakan untuk merancang sistem secara global adalah rancangan Data Flow Diagram. DFD terbagi dua yaitu Context Diagram (diagram konteks) dan DFD Levelled. Adapun perancangan global dari sistem yang baru adalah sebagai berikut.

1. Program Flowchart Evaluasi Pemohon Kredit Dengan Metode AHP.

Program flowchart implementasi metode AHP dalam mengevaluasi pemohon kredit ditunjukkan oleh Gambar 2. 


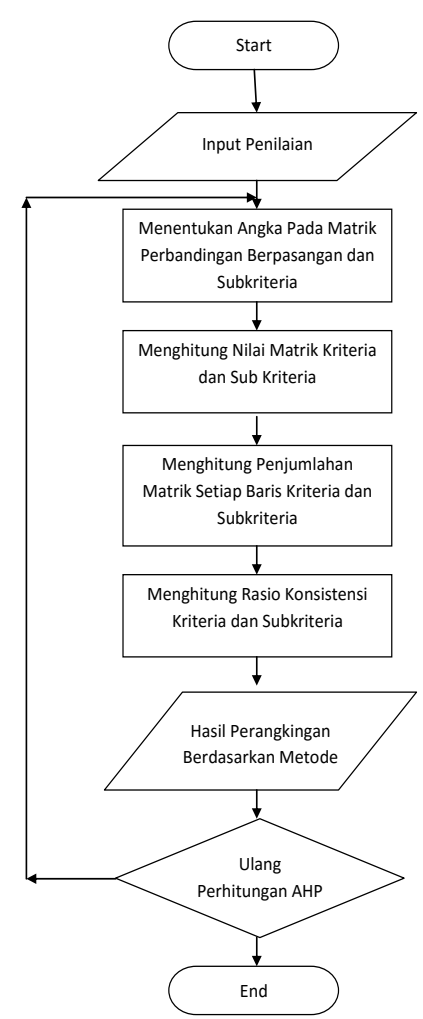

Gambar 2. Program Flowchart Evaluasi Pemohon Kredit Dengan Metode AHP

\section{Data Flow Diagram (DFD) Level 0}

Data Flow Diagram digunakan untuk memudahkan penggambaran sistem yang akan dikembangkan secara logika tanpa memperhatikan lingkungan fisik dimana data tersebut mengalir. Data Flow Diagram (DFD) level 0 untuk sistem yang diusulkan dapat dilihat pada Gambar 2.

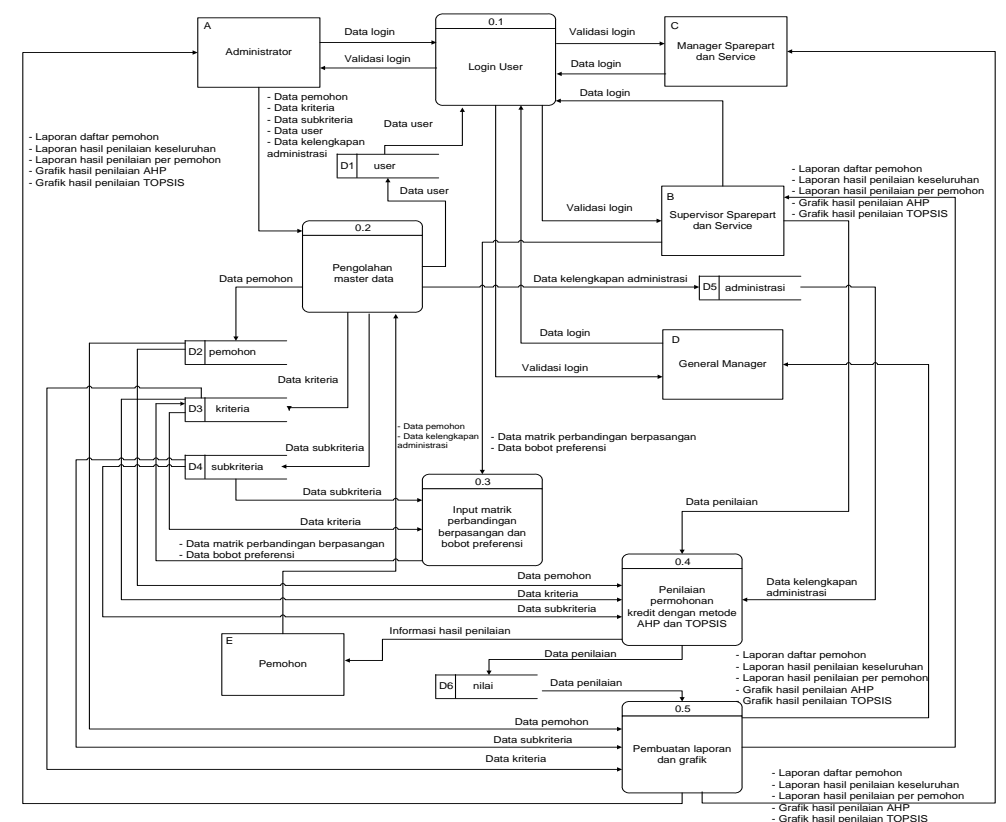

Gambar 2. Data Flow Diagram Level 0 


\section{Entity Relationship Diagram (ERD)}

Entity Relationship Diagram (ERD) merupakan komponen-komponen himpunan entitas dan himpunan relasi yang dideskripsikan lebih jauh melalui jumlah atribut-atribut (property) yang menggambarkan seluruh fakta dari sistem yang ditinjau. Gambar 3. adalah Entity Relationship Diagram dari sistem yang diusulkan.

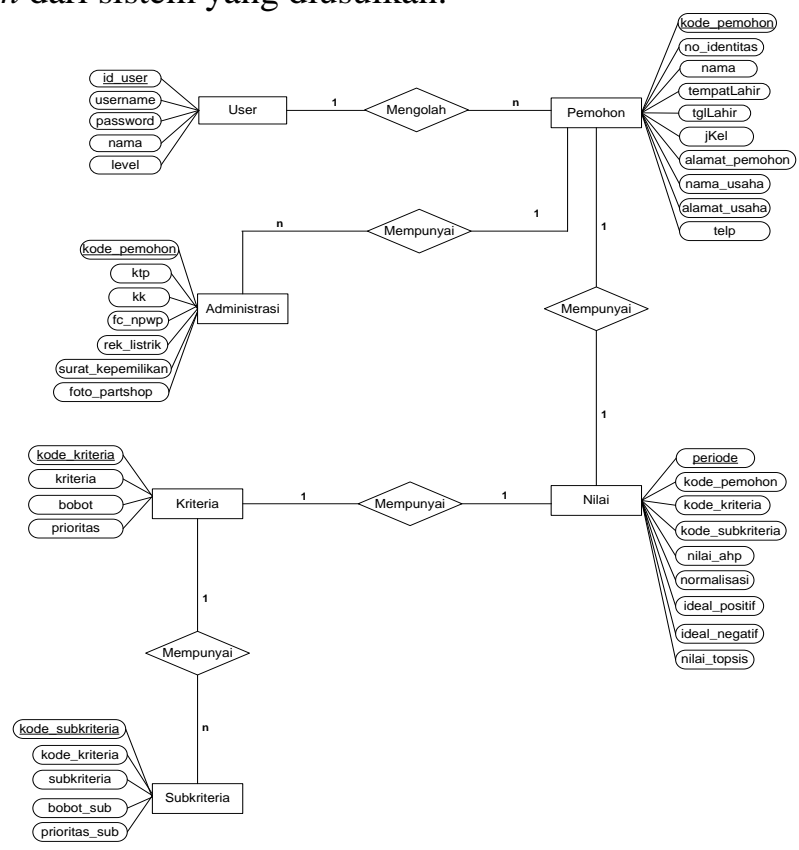

Gambar 3. Entity Relationship Diagram (ERD)

\section{Hasil dan Pembahasan}

Pada implementasi ini sistem dijalankan dan diamati untuk melihat kinerja yang dimiliknya. Implementasi dari sistem pendukung keputusan dalam mengevaluasi pemohon kredit suku cadang motor Suzuki pada PT. Riau Jaya Cemerlang Pekanbaru antara lain sebagai berikut.

1. Form Login

Form login digunakan untuk mengatur hak akses pengguna program. Form login terdiri dari username dan password. Berikut ini adalah tampilan dari form login.

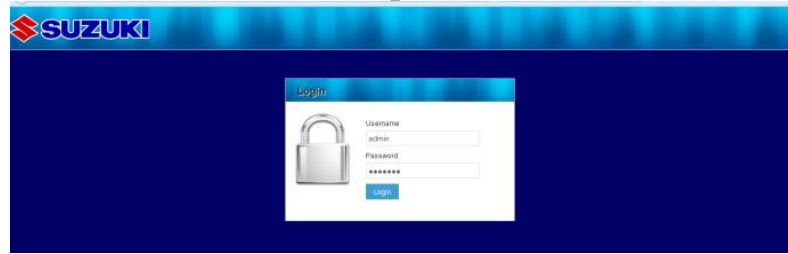

Gambar 5. Form Login

2. Halaman Utama

Jika login yang dilakukan benar, maka user akan diarahkan ke halaman utama pada sistem. Berikut ini adalah tampilan dari halaman utama dari sistem yang diusulkan. 

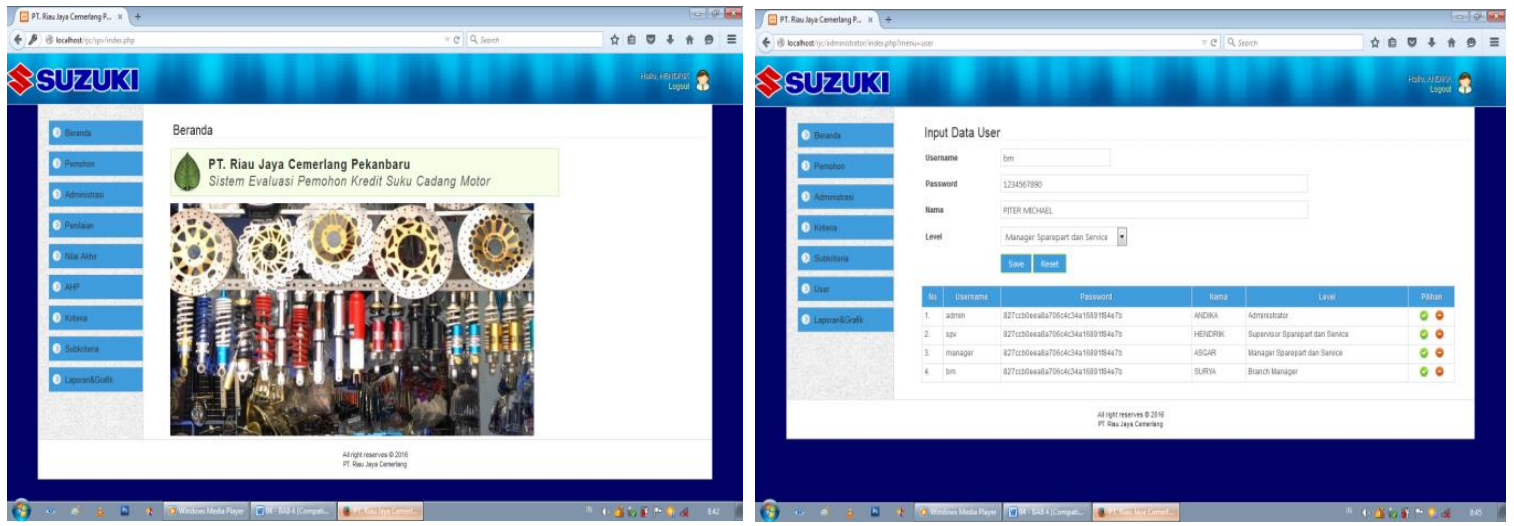

Gambar 6. Halaman Utama Supervisor Sparepart dan Service dan Administrator

3. Form Input Data Pemohon

Pada form input data pemohon, administrator dapat menginputkan data pemohon yang ada. Data yang diinputkan berupa kode pemohon, nomor identitas, nama, tempat lahir, tanggal lahir, alamat dan telepon serta nama unit usaha, dan alamat usaha. Berikut ini adalah tampilan dari form input data pemohon.

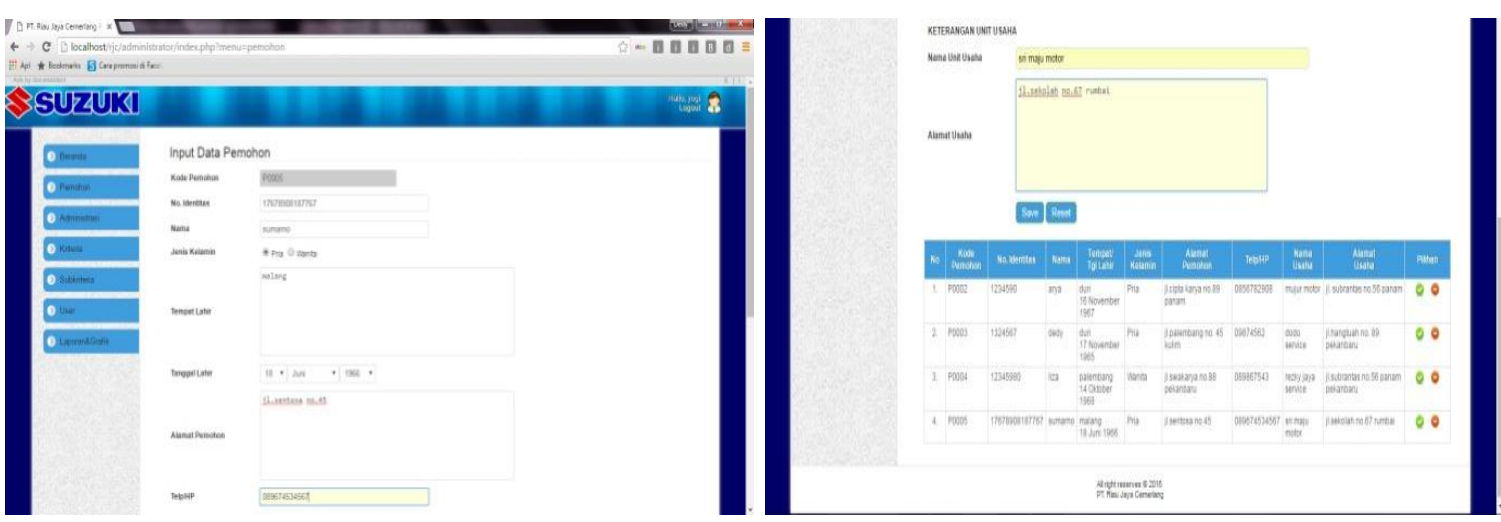

Gambar 7. Form Input Data Pemohon

4. Form Input Data Kelengkapan Administrasi

Pada form input data kelengkapan administrasi, administrator dapat menginputkan data kelengkapan administrasi dari pemohon yang sudah diinputkan datanya. Berikut ini adalah tampilan dari form input data kelengkapan administrasi.

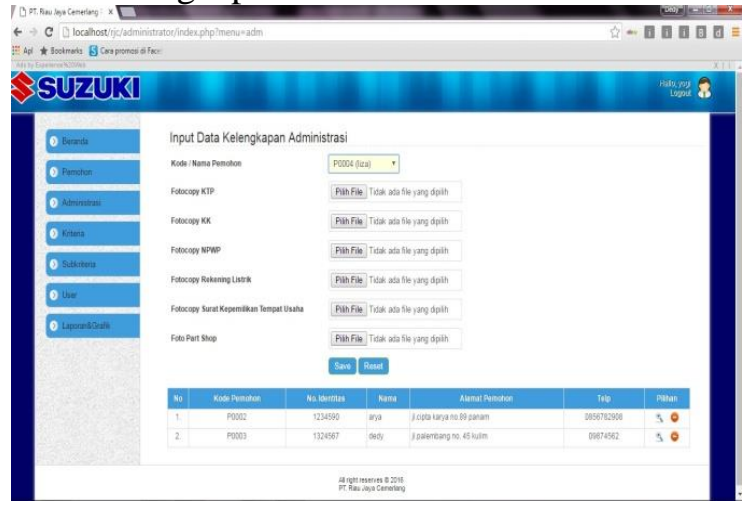

Gambar 8. Form Input Data Kelengkapan Administrasi 
5. Form Input Data Kriteria

Pada form input data kriteria, administrator dapat menginputkan data kriteria dan subkriteria penilaian yang ada. Berikut ini adalah tampilan dari form input data kriteria.

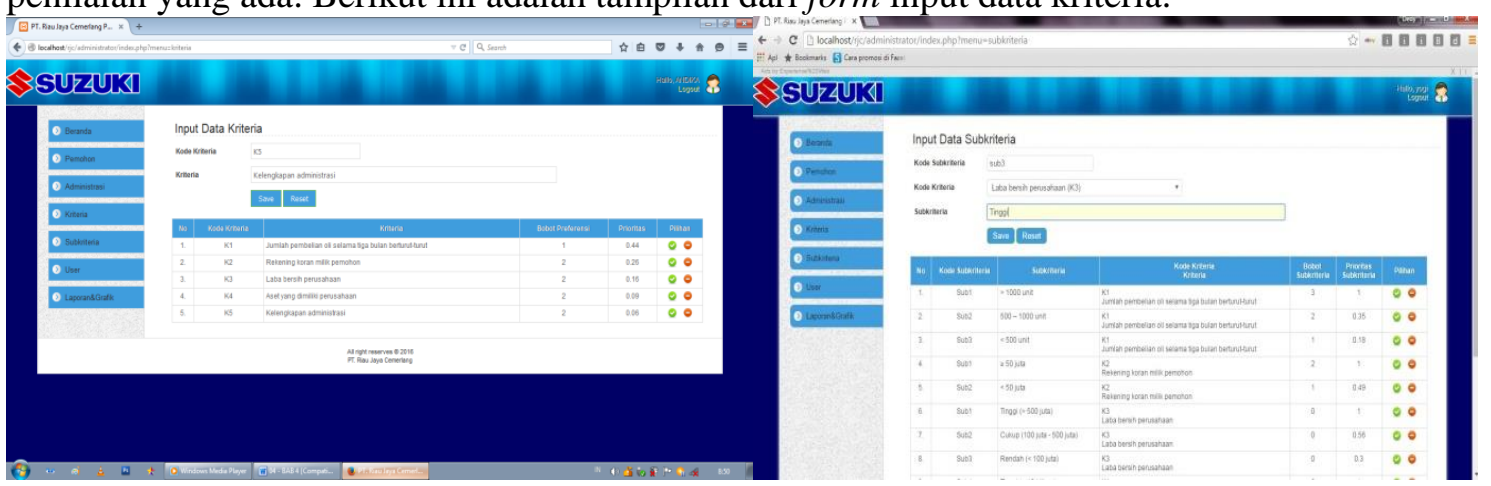

Gambar 9. Form Input Data Kriteria dan Subkriteria

6. Form Input Data Proses AHP dan Data Penilaian

Pada form input data proses AHP, Supervisor Sparepart Dan Service dapat menginputkan data matriks perbandingan berpasangan kriteria dan subkriteria. Selanjutnya dilakukan input data penilaian pemohon. Berikut ini adalah tampilan dari form input data proses AHP.

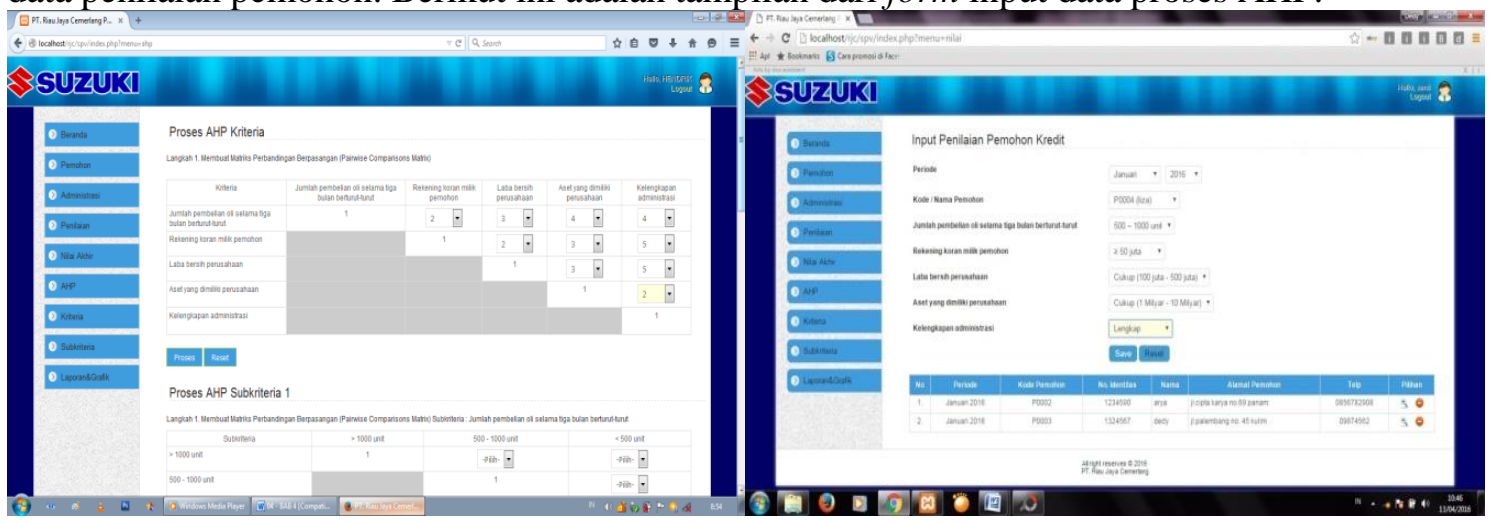

Gambar 10. Form Input Data Proses AHP dan Data Penilaian Pemohon

7. Laporan Daftar Pemohon

Pada laporan daftar pemohon, semua user dapat melihat data pemohon yang sudah diinputkan datanya ke database. Berikut ini adalah implementasi laporan daftar pemohon.

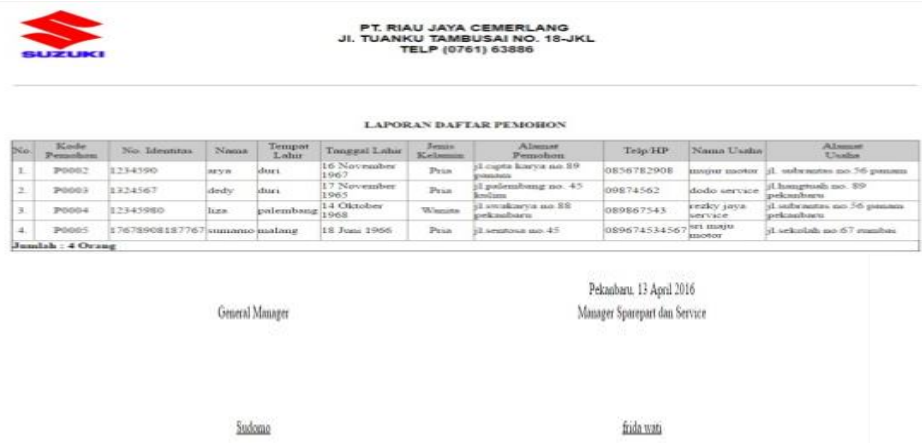

Gambar 11. Laporan Daftar Pemohon 
8. Laporan Hasil Penilaian Keseluruhan

Pada laporan hasil penilaian keseluruhan, semua user dapat melihat hasil penilaian keseluruhan yang sudah diinputkan oleh Supervisor Sparepart dan Service. Berikut ini adalah implementasi laporan hasil penilaian keseluruhan.
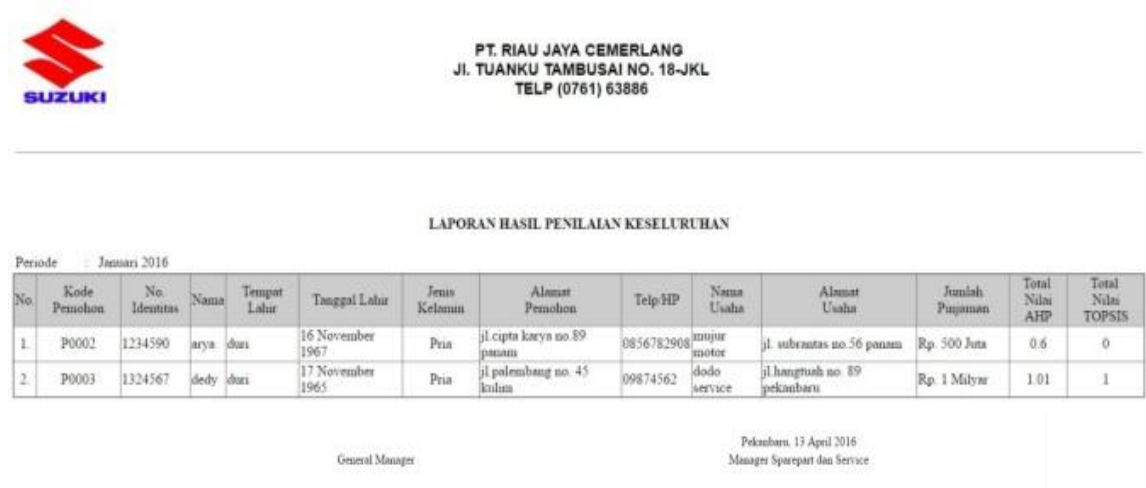

\section{Gambar 12. Laporan Hasil Penilaian Keseluruhan}

9. Laporan Hasil Penilaian Per Pemohon

Pada laporan hasil penilaian per pemohon, semua user dapat melihat hasil penilaian per pemohon yang sudah diinputkan oleh Supervisor Sparepart dan Service. Berikut ini adalah implementasi laporan hasil penilaian per pemohon.
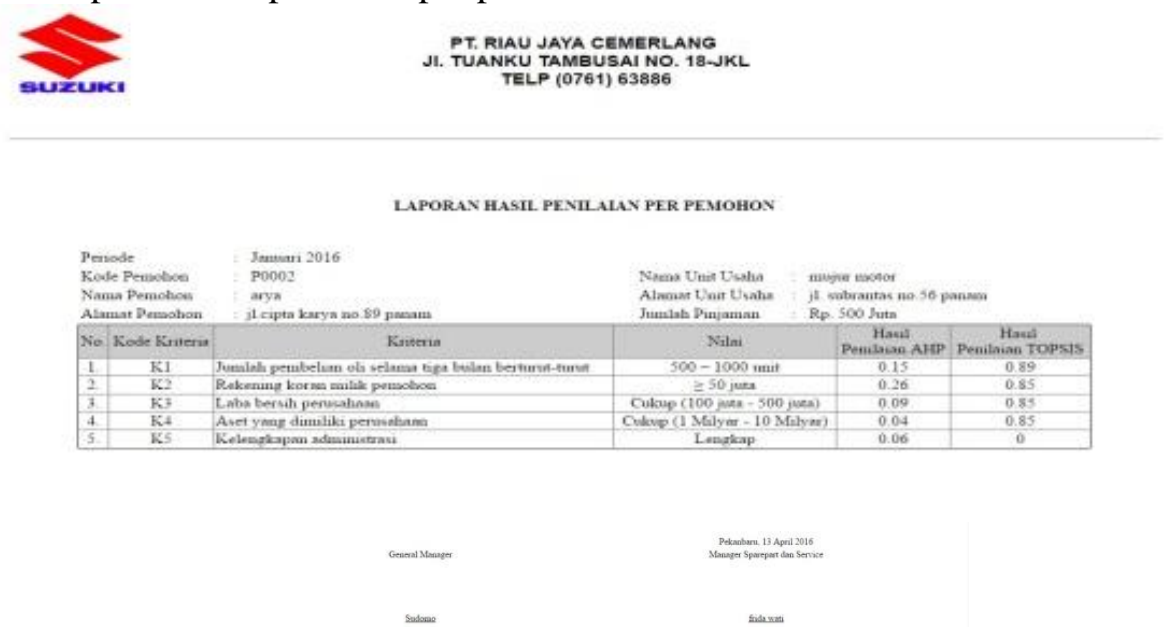

Gambar 13. Laporan Hasil Penilaian Per Pemohon

10. Grafik Hasil Penilaian AHP

Pada grafik hasil penilaian AHP, semua user dapat melihat hasil penilaian AHP dalam bentuk grafik. Berikut ini adalah implementasi grafik hasil penilaian AHP. 


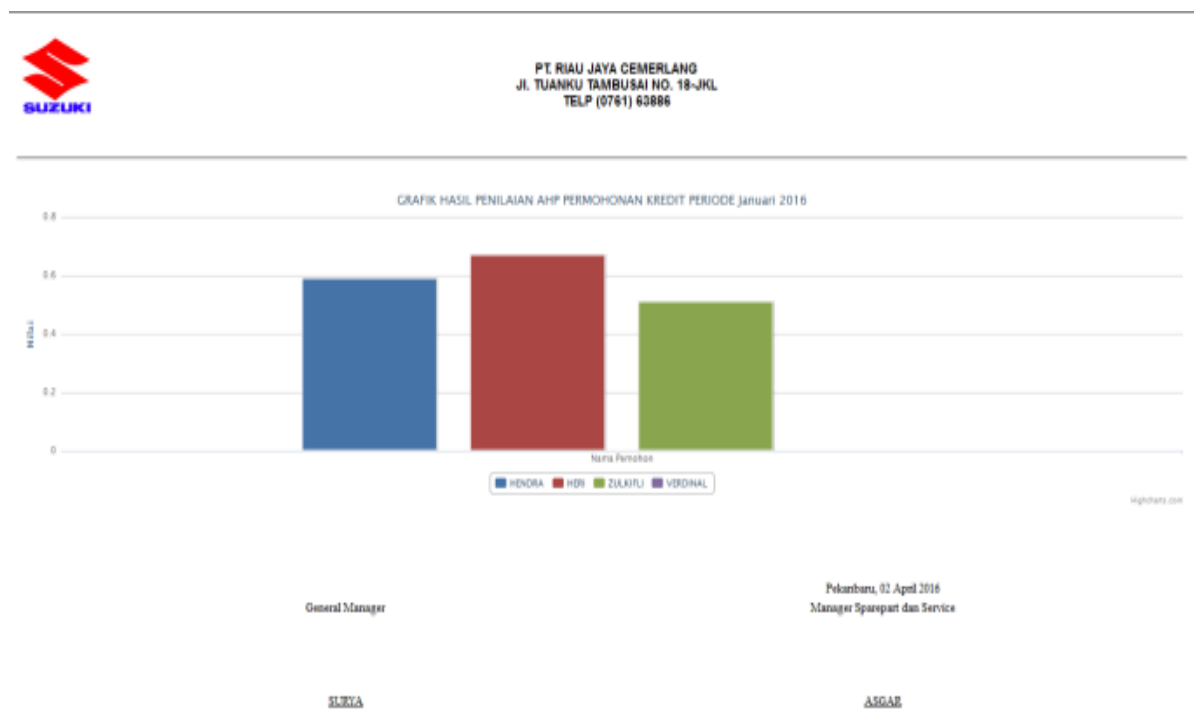

\section{Gambar 14. Grafik Hasil Penilaian AHP}

\section{Kesimpulan}

Berdasarkan hasil penelitian yang telah dilakukan penulis maka dapat disimpulkan beberapa hal sebagai berikut :

1. Dengan metode AHP dapat dilakukan evaluasi terhadap pemohon kredit suku cadang motor Suzuki pada PT. Riau Jaya Cemerlang Pekanbaru.

2. Dengan adanya sistem evaluasi pemohon ini maka Supervisor Sparepart dan Service tidak perlu melakukan penilaian dan pertimbangan secara manual karena sistem dapat mengolah data nilai yang diinputkan serta menyajikan rangking yang diperoleh pemohon.

3. Dari hasil penelitian maka dapat disimpulkan bahwa hasil perangkingan pemohon dengan metode AHP menunjukkan rangking teratas dapat prioritas untuk diberikan kredit.

\section{Daftar Pustaka}

[1] E. Sestri, "Penilaian kinerja dosen dengan menggunakan metode AHP Studi Kasus di STIE Ahmad Dahlan Jakarta," vol. 2, no. 1, pp. 100-109, 2013.

[2] P. R. Sukoharjo, "Sistem pendukung keputusan dengan metode," vol. 2, no. 1, pp. 1-15, 2012.

[3] "Metode dan Cara Perhitungan AHP _ herdi setiawan." .

[4] Kusrini. (2007). Konsep dan Aplikasi Sistem Pendukung Keputusan. Yogyakarta: Penerbit Andi.

[5] Marimin. (2010). Aplikasi Teknik Pengambilan Keputusan dalam Manajemen Rantai Pasok. Bogor : IPB Press. 